\title{
Job Interview: An Analysis of Communication Strategies Used by Thai Prospective Employees
}

\author{
Prathomwat Suraprajit \\ Faculty of Management Sciences, Kasetsart University Sriracha Campus, Thailand
}

\begin{abstract}
Communication strategies play a crucial role for all employees who use English as a second or foreign language. The present study then analyzed the communication strategies employed by the prospective Thai employees who participated in the job interview activity at a Thai university. An in-depth job interview was conducted for gaining the qualitative data. The data were later analyzed by using descriptive statistics. Related to the mixed taxonomy of Tarone (1980), Faerch \& Kasper (1983), and Dornyei \& Scott (1997), the results showed that the most frequently used strategies employed by Thai participants during the job interview were compensatory strategies (intra-actional strategies) followed by compensatory strategies (interactional strategies) and avoidance strategies. In addition, when grouping into sub-types, the findings indicated that the three most frequently used strategies were code-switching, asking for repetition, and message abandonment, respectively.
\end{abstract}

Index Terms - communication strategies, job interview, compensatory strategies, avoidance strategies

\section{INTRODUCTION}

Interview is an essential part of any recruitment processes (Keith, 2018). It is the first step for entering the real working world for the new graduates. And, it is the challenging step for the experienced job seekers who look for new opportunities for developing their working experiences. In the other words, it means that before becoming a new employee in the company or institution, a person must attend a job interview which is generally conducted in English language. However, the abilities and techniques in expressing ideas or answering the interview questions in English language are not easy for those whose English language is not their first language. Used in both government sections and private institutes worldwide, English is usually used in a job interview for testing the ability in using English language among the job applicants. Therefore, by exploring the strategies in using English for communication in the job interview questions among the L2 learners, the result would present some communication strategies (CSs) and suggest the future job interviewees some vital techniques which are beneficial for job interview.

\section{A. Communication Strategies in the Job Interview}

In the present state of the global economy, the knowledge of English is necessary for many people around the world. The people use English at school, college, and workplace. In the workplace, all four skills are necessary for all workers who use English for communication in their daily works both internally and externally. Acting as the medium language for international business, commerce and trade (Charles, 2007; Neeley, 2012; Reddy, 2016; Ahmad, 2016; and Ojanpera, 2014), English is unavoidable language for companies trying to compete in an international market. However, the situation in Thailand is opposite from its picture in the world economic stage. That is because the competence of English usage of Thai people is critical, especially comparing with those who are from the other countries in Southeast Asia. Although Thai people spend 12-15 years in learning English at school or college, they still face difficulties in using English, especially the ability in speaking. According to the world's largest ranking of countries and regions by English skills, the report from EF English Proficiency Index showed that the level of English skills of Thai people touches a low-level by ranking 64 out of 88 countries worldwide, and appears $16^{\text {th }}$ out of $21^{\text {st }}$ in Asia $(E F, 2018)$. By considering deeply in speaking skill, English oral communication has been the big problem for Thai people though they are in the modern age (Jarupan, 2013).

In the business world, many employers expect the high quality of English skill for communication from the job applicants. Thereby, the job interview is challenging for the applicants in selling their abilities in using English language. However, speaking English during job interview is not an easy task for many Thai applicants (Jaemjedrio et al., 2015). That is because they may face some problems during interviewing such as the responses to the interview questions and the use of English. The more difficulties may be that they may face problems of English comprehension, then they thought the things like complicated questions, the interviewers' accent, and the interviewer speaking too fast were the common problems which made them unable to understand and answer the questions (Jaemjedrio et al., 2015).

To overcome the stated threats, communication strategies is a key. That is because it can help the job applicants getting across with the speaking difficulties. It may also help them stay in a conversation and on the track though they still do not have the right answers at that time. To deal with the communication problems, the job applicants tend to rely on some sorts of strategies in order to help deliver a message to the interviewer(s) accurately and successfully. 
Therefore, it is worth to investigate the CSs employed by the senior Thai university students who are going to have a job interview after their graduation. That is because English is widely used for the job interview in Thailand. And, the benefits from the present study could help the job seekers acknowledging some communication strategies used in job interview. The results could also be applied for the pedagogy and future research.

\section{B. The Concepts of Communication Strategies}

Several researchers and scholars gave various definitions of communication strategies (CSs). Firstly, Selinker (1972) thought of CSs as one of the processes affecting second language acquisition. Tarone et al. (1976) then discussed CSs as a systematic attempt by the learner to express or decode meaning in the target language, in situations where the proper systematic target language rules have not been formed. Next, Corder (1978) defined CSs as a systematic technique employed by a speaker to express his own idea when faced with some difficulties. Later, in 1983, there are lots of comments toward CSs. Bialystok stated CSs as all attempts to manipulate a limited linguistic system in order to promote communication. Canale mentioned CSs as a tool for encouraging the interaction effectiveness. Faerch \& Kasper defined CSs as the potentially conscious plans for solving what to an individual presents itself as a problem in reaching a particular communicative goal. Stern (1983) demonstrated CSs as the techniques of dealing with difficulties in communicating in an imperfectly known second or foreign language. Then, in 1989, Poulisse comment on CSs as the strategies that a speaker used to solve the communication problem caused by the lack of right forms in the mental lexical. The speaker compensates either by going to the conceptual stage or by trying out alternative linguistics formulations. In addition, in 1994, Ellis thought of CSs as the procedural skills which learner used to overcome the inadequacies of their interlanguage resources. And, in 2004, Cohen considered CSs as a systematic attempt by the learner to express meaning by a target language in which the suitable systematic target language rules have not been formed.

\section{LITERATURE REVIEWS}

There found many earlier studies related to the field of communication strategies (CSs) worldwide. Yarahmedzehi et al. (2015) from Iran examined the CSs among Iranian learners and found that the learners employed compensatory strategies the most, and the proficiency plays role in the degree of strategy used. Then, they are the studies from Turkey. Yaman et al. (2013) investigated both speaking and listening strategies used by EFL students in Turkey. The results revealed that the participants delivered negotiation for meaning, compensatory and getting the gist strategies when they communicated. Elyildirim (2017) also investigated the CSs among forty Turkish students. The findings were that the learners avoided some structure when writing. Next, it is the evidence from Tunisia. The work of Ounis (2016) found that achievement strategies were the most frequency used when the participants spoke, whereas non-verbal strategies, negotiation for meaning and getting the gist were the most frequently used while listening. In Nepal, Manzano (2018) investigated the CSs among Nepalese adult learners in a speaking skill. The findings showed that the participants employed both verbal and non-verbal strategies by appearing avoidance strategies (in verbal) and achievement strategies (in non-verbal) the most frequently employed. In Vietnam, Thu \& Thu (2016) worked on the CSs among Vietnamese non-English major students. The results showed that compensatory was the highest used strategies. However, most students did not even know what CSs was. The another work from Vietnam was found in the study of Yanju \& Yanmei (2016) which found that modification devices was the most frequently used. In Mexico, Lopez (2011) explored the oral strategies employed by students in higher education. The CSs that they employed were asking for repetition, use of paraphrasing or synonyms for unknown words, and asking for message clarification. And, they tended to use the strategies according to their proficiency. Moreover, there are many works related to the CSs studies in Malaysia as found in Hua et al. (2012); Ugla et. al. (2012); Zulkurnain \& Kaur (2014); and Yanju \& Yanmei (2016). Hua et al. (2012) explored the CSs employed among international students in Malaysian University. The findings reported that code switching was the most employed strategy. Ugla et. al. (2012) then worked on CSs used by fifty Malaysian ESL learners. The results showed that the most used of direct CSs was retrieval strategy, whereas use of fillers was found the most employed for indirect CSs. Zulkurnain \& Kaur (2014) next discussed the types of oral CSs used by the diploma level ESL students. The findings showed that social-affecting strategies are the most used. And in Thailand, Suraprajit (2017); Binhayeearong(2009); Chuanchaisit \& Prapphal (2009); and Mongkolkeha (2008) also detected the communication strategies employed by Thai people with the various results.

\section{Methodology}

\section{A. The Participants}

In the present study, 66 senior Thai university students (52 females and 14 males) majoring in Management studying at the Faculty of Management Sciences in one public university in Thailand were recruited. They all registered and participated in the "English for job application and job interview" activity which was organized by the Faculty of Management Sciences during academic year 2018. The activity aimed to offer the senior Thai students a simulation to try the job interview in English before facing with the real situation in their future job interviews. The students from the Management major were chosen because they volunteered to participate in the stated program in which all senior 
students were welcome to consult in the issues related to the job application together with having a job interview. The selected participants were those who answered all questions being asked. For those who cannot answer some questions or at least one question were not considered.

\section{B. Instrument}

In order to get the qualitative data on how the participants cope with the oral job interview in English, the in-depth job interview using unstructured open-ended questions which are a tool for collecting the data was conducted in English (L2) instead of Thai (L1). By doing this, an in-depth understanding of the strategies employed by individuals would be revealed. These questions were chosen because they were the most frequently asked questions found in the general job interview. Some interview questions used in the present study are as follows;

1) Can you introduce yourself?

2) Why did you choose to study Management major?

3) Which job position would you like to apply for?

4) Why do you want to work in this position?

5) Why do you want to work with our company?

6) Can you tell me about your university life?

7) Can you talk about your strengths and weaknesses?

8) Can you tell me about the activities that you like to do in your free time?

9) Can you tell me about the activities that you gained during your study at the university?

10) What do you see yourself in five years?

11) What is the most achievement in your life?

12) What do you like and dislike the most while studying at the university?

13) Why should we hire you?

14) What does make you different from other people?

\section{Data Collection}

Before proceeding the data collection, the pilot study was conducted by presenting the job interview questions to the university students who enrolled in the business course which included the job interview session in its lesson in order to check the suitability of the topics, period of time using for individuals, or whether there was some mistakes with the context or not. After that, all oral interview questions were rechecked for more accuracy.

After that, the participants were invited to join the activity "English for job application and job interview" which was held during academic year 2018. The program was promoted via the faculty's website, Facebook, and announcement boards. The students who were interested in the project, then registered to participate in. After that he or she made an appointment with the interviewer for having a job interview.

On the interview day, each participant came to the interviewing room where $30-60$ minutes was spent for each interview. The researcher, acting as an interviewer, then informed the rules and condition of the program. Next, the interview was started with a small talk in which the interviewer asked the general questions such as the background of each participant, their hobbies, their interests, etc. The interviewer then went down to the business by asking the listed questions and discussing on the topics related to their applied position. The main purpose of this section was to encourage them to share their facts and opinions toward the stated interview questions by using English. All students who took part in this activity were asked the same questions. Acting as the interviewer, the researcher informed the participants who acted as the interviewees that their performances would be recorded by the cell phone and be shown them at the end of the activity in order to comment on their strong and weak points while interviewing. After that, the recordings were transcribed for analyzing.

\section{Data Analysis}

The qualitative data were then clarified by the types of CSs that were used. To identify the frequency of strategies used by the senior Thai university students, number of usage and percentage were detected.

The stage of data analysis could be summarized as follows:

1) Replaying the recording interview.

2) Transcribing the interview recording.

3) Checking the interview data script in detail.

4) Clarifying the CSs or making a list of CSs employed by Thai senior university students.

5) Grouping all CSs based on its characteristics. At this stage, two main CSs were found.

6) Identifying the two main CSs into its sub-categories.

7) Summarizing the total numbers of CSs in each sub-categories together with its percentage.

\section{RESUlTS AND DisCUSSION}

After the data were analyzed, the results of overall CSs employed by the senior Thai university students during the job interview were shown in Table 1. 
TABLE 1.

COMMUNICATION STRATEGIES USED By PARTICIPANTS IN JOB INTERVIEW

\begin{tabular}{|c|c|c|}
\hline Strategy & Frequency of use & Percentage \\
\hline 1) To stop in mind utterances & 42 & 15.107 \\
\hline 2) To mumble with audible/inaudible voices & 26 & 9.352 \\
\hline $\begin{array}{l}\text { 3) To switch English to Thai without bother to } \\
\text { translate }\end{array}$ & 92 & 33.093 \\
\hline $\begin{array}{l}\text { 4) To adjust Thai to English phonologically and/ } \\
\text { nor morphologically }\end{array}$ & 1 & 0.359 \\
\hline 5) To repeat words or phrases of one's own speech & 1 & 0.359 \\
\hline 6) To translate words from Thai to English & 3 & 1.079 \\
\hline $\begin{array}{l}\text { 7) To request direct or indirect help from the } \\
\text { interlocutor }\end{array}$ & 21 & 7.553 \\
\hline $\begin{array}{l}\text { 8) To ask for repetition when having } \\
\text { comprehension difficulties }\end{array}$ & 63 & 22.661 \\
\hline $\begin{array}{l}\text { 9) To request confirmation that something is } \\
\text { understood correctly }\end{array}$ & 2 & 0.719 \\
\hline 10) To laugh when don't understand & 27 & 9.712 \\
\hline 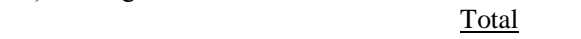 & 278 & 100 \\
\hline
\end{tabular}

As displayed in Table 1, the results from the English oral interview indicated that the total numbers of CSs used by the participants were 278. Then, they were grouped into ten strategies based on the similarities of their characteristics. Later, the findings demonstrated that the most frequently used strategy during the job interview was "to switch the language (L2: English to L1: Thai)" with the number of usage as 92 (33.093\%), followed by "to ask for repetition when having comprehension difficulties" with the frequency of use as $63(22.661 \%)$, and the third most used strategy was "to stop in mind utterance" with the total of use as $42(15.107 \%)$. In contrast, the least used strategies found in the present study were "to adjust L1 (Thai) to L2 (English) phonologically and/nor morphologically" and "to repeat words or phrases of one's own speech" with the same number of use as $1(0.359 \%)$, and the third rank was "to request confirmation that something is understood correctly" with the frequency of use as $2(0.719 \%)$.

TABLE 2

COMMUNICATION GROUPED BY MAIN AND SUB-CATEGORIES

\begin{tabular}{|c|c|c|}
\hline Strategy & Frequency of use & Percentage \\
\hline \multicolumn{3}{|l|}{ 1. Avoidance strategies } \\
\hline 1.1 Message abandonment: To stop in mind utterances & 42 & 15.107 \\
\hline \multicolumn{3}{|l|}{ 2. Compensatory strategies (Intra-actional strategies) } \\
\hline $\begin{array}{l}2.1 \text { Mumbling: To mumble with audible/ } \\
\text { inaudible voices }\end{array}$ & 26 & 9.352 \\
\hline 2.2 Code-switching: To switch English to & 92 & 33.093 \\
\hline \multicolumn{3}{|l|}{ Thai without bother to translate } \\
\hline $\begin{array}{l}2.3 \text { Foreignizing: To adjust Thai to English } \\
\text { phonologically and/nor morphologically }\end{array}$ & 1 & 0.359 \\
\hline $\begin{array}{l}\text { 2.4 Self-repetition: To repeat words or } \\
\text { phrases of one's own speech }\end{array}$ & 1 & 0.359 \\
\hline $\begin{array}{l}2.5 \text { Literal translation: To translate words } \\
\text { from Thai to English }\end{array}$ & 3 & 1.079 \\
\hline \multicolumn{3}{|l|}{ 3. Compensatory strategies (Interactional strategies) } \\
\hline $\begin{array}{l}\text { 3.1 Appeal for help: To request direct or } \\
\text { indirect help from the interlocutor }\end{array}$ & 21 & 7.553 \\
\hline $\begin{array}{l}\text { 3.2 Asking for repetition: To ask for repetition } \\
\text { when having comprehension difficulties }\end{array}$ & 63 & 22.661 \\
\hline $\begin{array}{l}\text { 3.3 Asking for confirmation: To request } \\
\text { confirmation that something is understood correctly }\end{array}$ & 2 & 0.719 \\
\hline 3.4 Facial expression: To laugh when & 27 & 9.712 \\
\hline Total & 278 & 100 \\
\hline
\end{tabular}

According to Table 2, after the CSs had been grouped into its category based on the mixed taxonomy of Tarone (1980), Faerch \& Kasper (1983) and Dornyei \& Scott (1997), it appeared two main categories which were avoidance strategies and compensatory strategies. Discussing on the avoidance strategies, the only one sub-category found was message abandonment. Considering the compensatory strategies, it could be divided into two sub-categories which were intra-actional strategies and interactional strategies. Then, the sub-types strategies of intra-actional strategies were mumbling, code-switching, foreignizing, self-repetition, and literal translation. And, appeal for help, asking for repetition, asking for confirmation, and facial expression were those belonging to interactional strategies. 
The most used strategies employed by the senior Thai university students during participating in the job interview were "compensatory strategies: intra-actional strategies" followed by "compensatory strategies: interactional strategies" and "avoidance strategies", respectively. By using compensatory strategies: intra-actional strategies, the participants tried to solve the communication difficulties by themselves, without looking for help from the interlocutor. In the other words, the interviewees preferred using their own resources or tactics, rather than appealing for assistance from the others when they encountered difficult situations while interviewing. It indicated that the participants attempted to have a smooth conversation by keeping their interaction with their interlocutors (Thu \& Thu, 2016). The findings from the present study were consistent with those found in the study of Binhayeearong (2009) which reported that intra-actional strategies were used more frequently than other strategies. Then, compensatory strategies: interactional strategies were the other popular category. These strategies were employed to ensure that their interlocutors understand their intended messages completely and accurately. When some problems or difficulties occurred during the communication, the use of interactional strategies encourage the communicators expand their conversation through smooth turn-takings and then they can deliver the completed comprehension of the intended message. These strategies were extensively employed by many participants from various studies (Maleki, 2010; Lopez, 2011; and Yanju\&Yanmei, 2016). And, the third most used strategies were avoidance strategies. This strategy is widely used among L2 learners when their limited knowledge of grammatical rules get them in trouble (Elyildirim, 2017), but not beneficial for learning a second language (Zhang, 2007). The learners could learn nothing when they try to skip with the problem, either by changing the communication purpose, evading the communication, or even cutting the communication short (Abunawas, 2012). The participants adopted these strategies when they could not transmit their intended message or get it across so that they avoided these problematic messages. However, the learners may get some benefits of these strategies. By using these strategies, the people can further their conversation even though they faced some problems or difficulties because of some reasons. Then, the participants could avoid making mistakes and increase fluency in conversation (Yanju\&Yanmei, 2016).

Classified into the sub-categories, the three most frequently used were code-switching, asking for repetition, and message abandonment, respectively. For more explanation, the results showed that code-switching was really popular among the senior Thai university students. Being the strategy which is employed by the bilinguals to deliver their interlocutor the genuine meaning of the intended message, code-switching is a widespread phenomenon in bilingual speech (Riehl, 2005) which requested a great deal of bilingual competence (Muysken, 1995). Then, most ESL learners have positive attitudes toward code-switching. They believe that it helps them to understand the target language and enables them to be more confident in mastering English (Nordin et al., 2012). Moreover, Thai teachers agreed that this strategy could make the comprehension among the students together with helping them getting a clear idea of the subject matter (Promnath \& Tayjasanant, 2016). The finding of the present study was consistent with the work of Chaiwichian (2007) who found that Thai learners switched more English to Thai when they are outside classroom. Another issue to be considered was that code-switching is more used by the low proficiency learners (Xiaoji, 2017; and Shanehsazzadeh \& Darani, 2017). In the other words, it showed the lack of target language proficiency among the participants who employed this strategy during their job interviews. Then, the participants used the strategies of "asking for repetition" the second most used. According to Somsai \& Intaraprasert (2011), the participants asked for repetition from the interlocutors when they could not understand the message clearly due to their unfamiliarity with an English accent or their limited linguistics knowledge. It is also possible that the participants were afraid of making mistakes. They might think that it would be better to ask someone else than to misunderstand the question. The participants then tried to handle the problems cooperatively by asking for repetition in order to have a mutual understanding with their interlocutors (Dabao \& Martinez, 2007). In the other words, employing these strategies is likely to help promoting mutual comprehension of the message in the interview. The result of the present study was consistent with those found in Mongkolkeha (2008). Moreover, the third most used strategy is message abandonment. This strategy is employed when the speaker begins to talk about a concept, but is unable to continue and stops in a mid-utterance because of language difficulties which might be about lacking vocabulary, facing difficulties in arranging the structure of their utterance, confusing to continue due to their nervousness, and being worried of making mistakes. Lots of scholars (Ounis, 2016; Chen, 2009; Ugla et al., 2013; Chuanchaisit \& Prapphal, 2009; and Nakatani, 2006) found and suggested that message abandonment is the most popular among the low proficiency L2 learners or less fluent speakers. This implies that the participants in the current study who employed the strategy of message abandonment may have a low proficiency in using English.

\section{CONCLUSION}

The objective of the present study was to investigate the communication strategies employed by senior Thai university students during their job interviews. In the current study, the participants relied on various strategies to cope with the problems or difficulties while having the interview. The overall strategies found in the present study revealed that the participants used most compensatory strategies and avoidance strategies when they faced problems or difficulties during their job interview. Grouped into sub-categories, the results showed that code-switching followed by asking for repetition and message abandonment were the most used strategies among senior Thai students during interaction with the interviewer. In the other word, the findings from the study suggested that Thai learners preferred the 
passive strategies rather than active strategies in order to further their conversations in the foreign language. In addition, the future study should focus on the active strategies which support the learners to communicate with the foreign interlocutors more effectively.

\section{ACKNOWLEDGEMENTS}

I would like to thank my colleagues at the faculty of Management Sciences, Kasetsart University for their valuable guidance throughout this work. Also, my thanks go to my grandfather, Assoc. Prof. Dr. Udom Piriyasing, for his inspiration and love.

\section{REFERENCES}

[1] Abunawas, S.N. (2012). Communication Strategies Used by Jordanian EFL Learners. Canadian Social Science, 8(4), 178-193.

[2] Ahmad, S.R. (2016). Importance of English Communication Skills. International Journal of Applied Research, 2(3), 478-480.

[3] Bialystok, E. (1983). Some factors in the selections and implementation of communicative strategies. In Faerch, C. \& Kasper, G., Strategies in interlanguage communication. London \& New York: Longman.

[4] Binhayeearong, T. (2009). Communication Strategies: A study of students with high and low English Proficiency in the M.3 English Program at Attarkiah Islamiah School. MA Thesis, Prince Songkla University, Songkla, Thailand.

[5] Canale, M. (1983). From communication competence to communicative language pedagogy. In Richards, J.C. \& Schmidt, R.W. (Eds.), Language and Communication. Harlow, UK: Longman.

[6] Chaiwichian, U. (2007). Thai-English code-switching of students in the mini English program (MEP). MA Thesis, Suranaree University Technology, Nakhon Ratchasima, Thailand.

[7] Charles, M. (2007). Language matters in global communication. Journal of Business Communication, 44(3), $260-282$.

[8] Chen, H.W. (2009). Oral communication strategies used by English major college students in Taiwan. MA Thesis, Chaoyang University of Technology, Taichung, Taiwan.

[9] Chuanchaisit, S. \& Prapphal, K. (2009). A study of English communication strategies of Thai university students. MANUSYA: Journal of Humanities, special issue (17), 100-126.

[10] Cohen, S.P. (2004). Relevance Theory, Action Theory and Second Language Communication Strategies. Second Language Research, 20(3), 289-302.

[11] Corder, S.P. (1978). Language-learner language. In Richards, J.C. (ed), Understanding Second and Foreign Language Learning. Rowley, MA: Newbury House.

[12] Dabao, A.M.F. \& Martinez, I.M.P. (2007). Negotiating meaning in interaction between English and Spanish speakers via communication strategies. Atlantis, 29(1), 87-105.

[13] Dornyei, Z. \& Scott, M.L. (1997). Review article: Communication strategies in a second language: definition and taxonomies. Language Learning, 47(1), 173-210.

[14] EF, (2018). EF English Proficiency Index - A Comprehensive ranking of countries by English skills. Retrieved on Dec 9, 2018 from www.ef.edu/epi/

[15] Ellis, R. (1994). The Study of Second Language Acquisition. Oxford: Oxford University Press.

[16] Elyildirim, S. (2017). Avoidance strategy in Foreign Language Production. Journal of Suleyman Demirel University Institute of Social Sciences, 28(3), 231-242.

[17] Faerch, C. and Kasper, G. (1983). Plans and Strategies in Foreign language Communication. Strategies in Interlanguage Communication. London: Longman.

[18] Hua, T.K., Nor, N.F.M. \& Jaradat, M.N. (2012). Communication strategies among EFL students - An examination of frequency of use and types of strategies used. GEMA Online Journal of Language Studies, 12(3), 831-848.

[19] Jaemjedrio, S., Dispany, E., Tantanapornchai, Y., \& Charunrochana, J. (2015). A study of English communication problems during an employment interview. $7^{\text {th }}$ International Conference on Humanities and Social Sciences "ASEAN 2015: Challenges and Opportunities" (Proceedings), $27-39$.

[20] Jarupan, S. (2013). The English Oral Communication Competence of Thai Engineering Students. International Journal of Scientific and Research Publications, 3(3), 1-9.

[21] Keith, R. (2018). How important is the interview in the hiring process? Retrieved on May 15 , 2019 from http://www.selectinternational.com/blog/how-important-is-the-interview-in-the-hiring-process.

[22] Lopez, M.M. (2011). Speaking strategies used by BA ELT students in public universities in Mexico. MEXTESOL Journal, 35(1), 1-22.

[23] Maleki, A. (2010). Techniques to Teach Communication Strategies. Journal of Language Teaching and Research, 1(5), 640646.

[24] Manzano, B.A. (2018). Examining the oral communication strategies used by a group of Nepalese adult learners in an ESL context. 3L: The Southeast Asian Journal of English Language Studies, 24(1), 84-96.

[25] Mongkolkeha, C. (2008). English communication strategies: A case study of hotel employees $\quad$ on Koh Samui. Independent Study, Kasetsart University, Bangkok, Thailand.

[26] Muysken, P. (1995). Code switching and grammatical theory. In Milroy, L. \& Muysken, P. (Eds.), One speaker, two languages. Cross disciplinary perspectives on code-switching, 177-198. NY: Cambridge University Press.

[27] Nakatani, Y. (2006). Developing and oral communication strategy inventory. Modern Language Journal, 90, 152-167.

[28] Neeley, T. (2012). Global business speaks English. Harvard business review, 90(5), 116-124.

[29] Nordin, N.M., Ali, F.D.R., Zubir, S.I.S.S., and Sadjirin, R. (2012). ESL learners' reactions towards code switching in classroom settings. $6^{\text {th }}$ International Conference on University Learning and Teaching (In CUIT 2012).

[30] Ojanpera, M. (2014). Effects of using English in business communication in Japanese-based multinational corporations. Thesis, M.A. in International Business, University of OULU. 
[31] Ounis, T. (2016). Exploring the use of oral communication strategies by high and low proficiency learners of English: Tunisian EFL students as a case study. International Journal of Humanities and Cultural Studies, 3(1), 1077-1098.

[32] Poulisse, N. (1989). The influence of task and proficiency related factors on the use of communication strategies: A quantitative analysis. Language Learning, 39(1), 15-46.

[33] Promnath, K. \& Tayjasanant, C. (2016). English-Thai code-switching of teachers in ESP classes. PASAA, 51, 97-126.

[34] Reddy, M.S. (2016). Importance of English Language in Today's World. International Journal of Academic Research, 4(2), 179-184.

[35] Riehl, C.M. (2005). Code-switching in bilinguals: impacts of mental processes and language awareness. In Cohen, J., McALister, K.T., Rolstad, K. and MacSwan, J. (Eds.), ISB4: Proceedings of the $4^{\text {th }}$ International Symposium on Bilingualism, 1945-1959. Somervill, MA: Cascadilla Press.

[36] Shanehsazzadeh, M. \& Darani, L.H. (2017). Functions of code-switching strategies among Iranian EFL learners and their speaking ability improvement through code-switching. International Journal of Foreign Language Teaching \& Research, 5(8), 97-109.

[37] Selinker, L. (1972). Interlanguage. IRAL, 10, 209-231.

[38] Somsai, S. \& Intaraprasert, C. (2011). Strategies for coping with face-to-face oral communication problems employed by Thai university students majoring in English. GEMA Online ${ }^{T M}$ Journal of Language Studies, 11(3), 83-96.

[39] Stern, H. (1983). Fundamental Concepts of Language Teaching. Oxford: Oxford University Press.

[40] Suraprajit, P. (2017). Communication strategies used by Thai service providers in Pattaya City, Thailand. International Journal of Arts and Sciences, 9(4), 71-82.

[41] Tarone, E., Cohen, A.D. \& Dumas, G. (1976). A closer look at some interlanguage terminology: A framework for communication strategies. London: Longman.

[42] Tarone, E. (1980). Communication strategies foreign talk and repair in interlanguage. Language Learning, 417-431.

[43] Thu, N.T.K. \& Thu, N.T. (2016). Oral English communication strategies among Vietnamese Non-majors of English in intermediate level. American Journal of Educational Research, 4(3), 283-287.

[44] Ugla, R.L., Adnan, N.A. \& Abidin, M.J.Z. (2012). Study of the communication strategies used by Malaysian ESL students at tertiary level. International Journal of English Language Education, 1(1), 130.139.

[45] Xiaoji, W. (2017). Comparative study on instructors' and students' code-switching in an EFL class. Cross-Cultural Communication, 13(8), 44-53.

[46] Yaman, S., Irgin, P., \& Kavasoglu, M. (2013). Communication strategies: Implications for EFL university students. Journal of Educational Sciences Research International E-Journal, 3(2), 255-268.

[47] Yanju, S. \& Yanmei, S. (2016). Communication Strategies Used by Middle Eastern Postgraduate Students at Service Encounters in University Malaya. European Journal of Language and Literature Studies, 2(2), 40-45.

[48] Yarahmedzehi, N., Saed, A., \& Farzane, S.S. (2015). Proficiency level and choice of communication strategies: A case of Iranian EFL Learners: Iranian Journal of English for Academic Purpose, 4(1), 118-132.

[49] Zhang, Y. (2007). Communication Strategies and Foreign Language Learning. US-China Foreign Language, 5(4), 43-48.

[50] Zulkurnain, N. \& Kaur, S. (2014). Oral English Communication Difficulties and Coping Strategies of Diploma of Hotel Management Students at UiTM. 3L: The Southeast Asian Journal of English Language Studies, 20(3), 93-112.

Prathomwat Suraprajit is an assistant professor at Faculty of Management Sciences, Kasetsart University Sriracha Campus. His research interests are English language teaching and ESP. 